\title{
Reform on the Mode of Training Legal Personnel in Applied Technology Universities
}

\author{
Guangkun Sun \\ Educational Scientific Research Office \\ Huanghe Science and Technology College \\ Zhengzhou, China 450063
}

\begin{abstract}
Legal education in colleges and universities is to cultivate legal talents for the society and the country. With the development of society, especially the establishment and improvement of socialist market economy and the deepening of reform and opening up and the implementation of the strategy of administering the country according to law, more legal talents are needed in society. As more and more people starting business with creative method, instead of only being equipped with legal knowledge, creative legal personnel is required.
\end{abstract}

Keywords-law; education; training mode

\section{INTRODUCTION}

"Any social practice activities have the intended purpose. As a social activity to cultivate personnel, education should be started from and ended at the point that what kind of talents to be cultivated." Legal education in colleges and universities is to cultivate legal personnel for the society and the country. With the development of society, especially the establishment and improvement of socialist market economy and the deepening of reform and opening up and the implementation of the strategy of administering the country according to law, more legal talents are needed in society. As more and more people starting business with creative method, instead of only being equipped with legal knowledge, creative legal personnel is required. Legal personnel that is needed in the background of innovation and entrepreneurship is the same as what has been mentioned in the Higher Education Law. As Article 5 in it stipulates that one of the tasks of higher education is to cultivate innovative personnel with practical ability. Paragraph 2 of Article 16 strengthens that undergraduate education should enable students to grasp more systematic basic theories and disciplines and basic knowledge of related skills and methods. That is to say, students should be able to have the primary ability to do study and work. As what has been put in Catalogue and Introduction of Undergraduate Specialty in Regular Institution of Higher Education, training of legal majors should be focused on quality education and capacitybuilding. As a practical discipline, legal education should be distinctive and innovative in the personnel. At present, the cultivation of traditional legal personnel is still focusing on books and theoretical knowledge, while ignoring the system to cultivate students' practical ability. This problem is obvious in applied talents training mode. Legal education is a practical subject for staring business and innovation, while this kind of talents cannot be cultivated through traditional teaching method.

II. INNOVATION AND STAR-UP BUSINESS SHOULD BE LINKED TO CARRY OUT THE REFORM OF LEGAL PERSONNEL TRAINING MODE

The current Chinese legal personnel training mode is learned from the former Soviet Union's mode. The fundamental defect of this kind of mode is that its range of specialty is too narrow, which seriously hinders the development of students' comprehensive quality, thus it cannot cultivate innovative personnel for social need. Under the background of innovation and start-up business, legal personnel training mode needs to adhere to the following principles.

\section{A. Serve the Cultivation of Innovative and Star-Up Business Personnel}

According to the development orientation of schools, the traditional training mode can be divided into two types: research-oriented training mode and application-oriented training mode. Personnel that has been cultivated by these two types of training mode is "dumbbell-shaped", research-oriented universities emphasis too much on theoretical teaching, while ignore the practice. On the contrary, application-oriented universities strengthen too much on pragmatism while ignore legal theory study. Thus those legal personnel with too many theories can't do practical work, those can do well in practice do not know much about legal theory. As one of the most famous private university in China, Huanghe S\&T College is now applying the integrated personnel training mode -"undergraduate education + vocational education", which can help the cultivation of legal personnel for innovation and startup business.

\section{B. Meet the Need of Social Development}

Legal education is mostly for practical issues in society. For the economic and social development, there are different ways of cultivating different kinds of legal personnel, which are as follow. The mission of first kind of personnel is to promote the legal construction of the country and the development of law, which means that this is the top level legal personnel. They need to have a strong theoretical foundation, deeply understand the history of law development, 
predict the development of law, understand the foreign legal system and find out the lack of domestic law, then put forward new ideas. Most of these people are in research or higher education institutions. The second kind is teachers of colleges and universities who are responsible to cultivate legal personnel. They should have the theoretical knowledge and skills of law and the teaching method and skills as well. The third kind is judicial personnel who use their own theoretical knowledge serve for the economic and technological development, such as judges, prosecutors, public security officers, lawyers, legal advisers, impartial personnel and other legal service personnel.

\section{Explanation of Innovative Legal Personnel and Business Star-Up Legal Personnel}

As we see these two different kinds of personnel separately, the first one is for the advancement of national legal construction and the development of law disciplines. While business start-up personnel are those people, like lawyers, legal advisers and other legal services personnel. But innovative and legal personnel are those graduates or undergraduates who can carry out the career development plan scientifically and can serve the social development with their own skills according to the form of economic organization with innovative ideas, instead of those great academic people or legal workers who can apply knowledge into practice. Thus, we can know that innovative and business star-up legal personnel can be trained by all kinds of universities and colleges.

\section{REFORM OF LEGAL PERSONNEL TRAINING MODE UNDER THE BACKGROUND OF INNOVATION AND START-UP BUSINESS}

Universities can be divided into research-oriented universities and application- oriented universities according to their training mode. In another point of view, the classification is not accurate. Fundamentally, no matter what kind of university, the graduates will participate in the work, their legal knowledge should be applied in the end. The difference is that the nature of the work is different, some are to solve the practical problems of judicial practice, and some are for the theoretical problems of law. Thus, all of them are applicationoriented. In other disciplines, there are high-level application technical personnel and general application technical personnel, in fact, there is no distinction between high level and general personnel. The only difference is that the division is different. So the author has divided it into theoretical personnel training and practical personnel training, which can help solve both theoretical problems and practical problems.

\section{A. Application-oriented Legal Personnel Training Mode}

There is a saying of Chinese legal universities and colleges -- "four kings, five politics and laws". "Four kings" refers to Peking University Law School, Renmin University of China Law School, Wuhan University Law, Jilin School, Jinlin University Law School; "five politics and laws" refers to China University of Political Science and Law, Northwest University of Politics and Law, Southwest University of Political Science and Law, Zhongnan University of Economics and Law, East China University of Political Science and Law respectively. These law schools above are suitable for the cultivation of application-oriented personnel in the consideration of their comprehensive strength. If we think it from the learning stage of students, it is suitable for the cultivation of researchers, because there are master's and doctor's degree. The theoretical knowledge needed to solve the problem of legal theory and judicial practice is different, and the way of thinking in solving problems is also different. Therefore, the teaching methods should be differentiated in cultivating these talents.

1) The selection of teachers. Teachers should have the following capabilities: First, they should be export in legal theories and research methods vertically. Second, it doesn't matter if they don't know all departments of the law, but they should know well about their own field by reading books both in their own country and from foreign countries; and they should be able to know the current condition and developing trends in the near future. Third, the teachers should have the special ability to find the problem that exist in judicial practice and then do study on it with innovative idea.

2) The selection of textbook: This personnel training mode requires more about textbook. The content of it should be authoritative and profound. It is necessary to be broad and have different schools of view. Some monographs can be recommended textbooks for elective courses, for example, On Prime and Punishment by Cesare Bonesana Beccaria, which was written 200 years ago. But many theories in this book are still new to us, and so it will be in 200 years.

3) Curriculum setting: As the theoretical application personnel are cultivated to solve theoretical problems, there should be more theoretical classes than practical ones in curriculum design. Graduation thesis should be the main task for them, which can help them conclude their knowledge and research theory, it can also help them improve innovative ability, practical ability and overall quality.

4) Teaching method: For the cultivation of this kind of personnel, it should be focus on teaching mainly. For example, Freshman Seminar is conducted with a topic in small groups with a professor. They will do panel discussions, oral arguments and writing exercises under the direction of the professor. This teaching method can not only make students master difficult points, it can also help them form their own ideas.

\section{B. The Training Methods of Application Technical Personnel}

1) The selection of teachers: Teachers should be qualified in the following conditions: they should be double capability trainers. It is necessary for them to have a teacher certificate, and also a lawyer practicing certificate. Those teachers need to have theoretical knowledge, but also some experience in judicial practice; they should be familiar with litigation or nonlawsuit business. At the same time, they are supposed to be able to solve practical problems.

2) The selection of textbook: Textbooks under this personnel training mode should be combined with China's current reality and should be closely integrated with judicial 
examination books issued by the national judicial department. As those who want to engage in judges, prosecutors, lawyers and other legal practice must pass the national judicial examination. In other words, however well one can do in legal knowledge, if he do not pass national judicial examination, he will not be qualified to engage in legal practice.

3) Curriculum setting: Compared with the theoretical application personnel training mode, there will be more practice. Practice courses will be accounted for 30-40\%. Graduation thesis is mainly by their designing, which is around practical judicial problems. Graduation design can help students use the theoretical knowledge, skills, and the ability to solve complex problems, so that students can strengthen their knowledge of the law to improve their ability in the practice and research.

4) Teaching methods: Teaching methods should be based on case study. We can learn from "Legal Clinic" personnel training mode from the USA. It is a well-known practical curriculum in the USA in the 1960s. As its name implies, it is characterized by imitating medical college clinic training form. Clinic teachers guide students in their practical application and promoting their understanding of law and legal professional awareness [3]. This kind of training mode can help cultivating legal personnel, doing legal services and soling practical legal issues.

\section{CONCLUSION}

In short, under the background of innovation and business start-up, the reform of legal personnel training mode should insist on serving for social development. It should start from the allocation of teachers, selection of textbooks, and arrangement of theoretical and practical curriculum. Thus, more and more legal personnel will be cultivated.

\section{REFERENCES}

[1] Du Chengming. Reform of Legal Education and Exploration of Legal Experiment Teaching Mode. Xiamen: Xiamen University Press, 2011.12

[2] Ma Jigang. Theoretical Research and Practical Exploration of Innovative Talents Cultivation in Comprehensive Universities. Chengdu: Sichuan University Press, 2006.09

[3] Jin Guohua. A New Probe into the Cultivation of Application-oriented Personnel in Colleges and Universities. Shanghai: Shanghai Academy of Social Sciences Press, 2007.06 